\title{
Conflicts in the countryside: the emerging awareness of the peasants
}

Jianrong Yu

\section{OpenEdition}

1 Journals

Édition électronique

URL : http://journals.openedition.org/chinaperspectives/1973

DOI : 10.4000/chinaperspectives. 1973

ISSN : 1996-4617

Éditeur

Centre d'étude français sur la Chine contemporaine

\section{Édition imprimée}

Date de publication : 15 septembre 2007

ISSN : 2070-3449

Référence électronique

Jianrong Yu, "Conflicts in the countryside: the emerging awareness of the peasants », China

Perspectives [En ligne], 2007/3 | 2007, mis en ligne le 01 septembre 2010, consulté le 28 octobre 2019.

URL : http://journals.openedition.org/chinaperspectives/1973; DOI : 10.4000/chinaperspectives.1973

(C) All rights reserved 


\title{
Conflict in the Countryside
}

\author{
Emerging Political Awareness among China's Peasants
}

\author{
YU IIANRONG
}

\section{Based on field investigations conducted in Hengyang County (Hunan Province), this article explores the rights} defence movement among Chinese peasants, focusing on the legality of the movement

$\mathrm{T}$

This article is a contribution to our understanding of the Chinese peasant rights defence movement, and references the works of Parsons ${ }^{(1)}$ in highlighting the pivotal role of three modalities of action: "interest" (as the basis of peasant action), "legality" (as the feature of their action), and "custom" (as the method of their action).

Located in central China, and typical of China's agricultural economic region, Hengyang County in Hunan Province provides the evidence for analysis. The peasants and peasant leaders of this county who have organised this rights defence movement have already attracted a high degree of attention among Chinese scholars, and have influenced the government's agricultural policies. ${ }^{(2)}$ This article is based on the author's own follow-up interviews with leaders of the rights defence movement.

\section{The Objectives of Action and the Expression of Interest}

Interest is usually considered a key factor in social action. "By way of the category of 'interest', we can on the basis of the shared expectations of actors work out the orientations of 'rationality of goals' in order to understand the unity of their action." ${ }^{3)}$ What is the interest, then, of the peasants who take part in the movement to protect their rights? In other words, what kind of interest can become an objective of the rights defence movement?

An empirical fact in our long-term observation of Hengyang County's rights defence movement is the participants' consistent avoidance of the issue of "interest", especially the question of their own interest. Peng Rongjun, a leader of the resistance movement, put it to me in this way:

These government officials said they would look after my interests. I made my position clear to them. "You talk about interests with me.... You want to meet my interests, but you haven't acted to resolve matters in the interest of the peasants. My own interest is a small affair, but if you resolve the peasant issue, then my interests will be served along with everyone else's." From their point of view, if I accept anything from them, then they will be using their economic means to control me, Peng Rongjun, and in my heart I know that is not right. ${ }^{(4)}$

For leaders of the rights defence movement such as Peng Rongjun, the interest justifying their action is not merely economic, but rather reflects the opinion of the masses. Even more important, they insist that the movement takes action, not on behalf of the personal interests of the participants, but rather in the interests of all, and most particularly to protect the interests of the villagers from infringement by the local government and lower-level cadres. There are three aspects to this. First, any policy laid out by the central government can be used to defend the peasants' interests. Second, these interests are infringed upon at the local level of government, and their protection requires considered action. In this regard, interest and infringement are interrelated; it is through illegal infringement that interest necessarily appears. Third, the plight suffered by the villagers being collective, any specific infringement becomes the violation of everyone's "interest". In the words of Ling Chunwei, another leader of Hengyang County's peasant rights defence movement:

I wanted to protect the rights of the peasants, and the first time I petitioned the authorities, there were some people, for example some lawyers, who wanted to protect my interests. I wondered why, because then I would also be obligated to protect theirs.

1. Parsons, T. Shehui Xingdong de Jiegou (The Structure of Social Action), Trans. Zheng Mingde, Xia Yunan and Peng Gang, Shilin Chubanshe, 2003, p. 728. Quotations in this article are translated back from the Chinese edition.

2. Yu Jianrong. "Nongmin You Zuzhi Kangzheng ji qi Zhengzhi Fengxian" (The Organised Resistance of Peasants and Political Danger), Zhanlüe yu Guanli, 3, 2003.

3. Parsons, T, op. cit..

4. Interview with Peng Rongjun, 27 February 2003. 
An elderly protester holds up documents relating to a land dispute

Our purpose was to make the peasants aware of which rights and interests were being infringed. I told the peasants about the government policies and printed them out. We attracted their attention with lights and loudspeakers and told them: the government wants to take advantage of us again, and what Old Ling was saying was true. There are documents from the upper echelons that we must denounce! And we have to oppose what is not reasonable! If you do not act, the government will stir up confusion, and the work of the cadres will be easy. If everybody knows how to protect their rights and interests, then the cadres will have to mind their steps. ${ }^{(5)}$

Ling Chunwei's earliest rights defence action related to the unfair treatment he received concerning taxation, which involved his personal interest. But what he expresses here is the collective interest of the peasants, which is bestowed by policy and based on "documents". The government's infringement on the "interest" of the peasants requires spokesmen for the peasants to come forward to resist the unfair treatment and protect their rights. This highlights the rational nature of the peasant rights defence movement and also explains the heroic tone of the movement's leadership. Ling Xuewen, another leader of the peasant rights defence movement, says:

The first time I petitioned the authorities, it was not about my own family's problems, and now when I petition the authorities it is still about collective issues. I often speak out against injustices, but these also do not involve my personal interest. When we fight for the Party's policies, for the collective interest, for the political rights of the masses, we have nothing to fear. I have made it clear to the head of the provincial bureau of letters and visits that I would rather die than capitulate. ${ }^{(6)}$

Liu Defa, another leader of the resistance movement, gave an even clearer explanation:

Last year the Hengyang County government issued a document to our peasant association; he personally handed it to me, so in the end I attended. The vice chief of the bureau of civilian affairs came to my home, and the deputy county chief came in person to see me. I told him that the first time I was de-

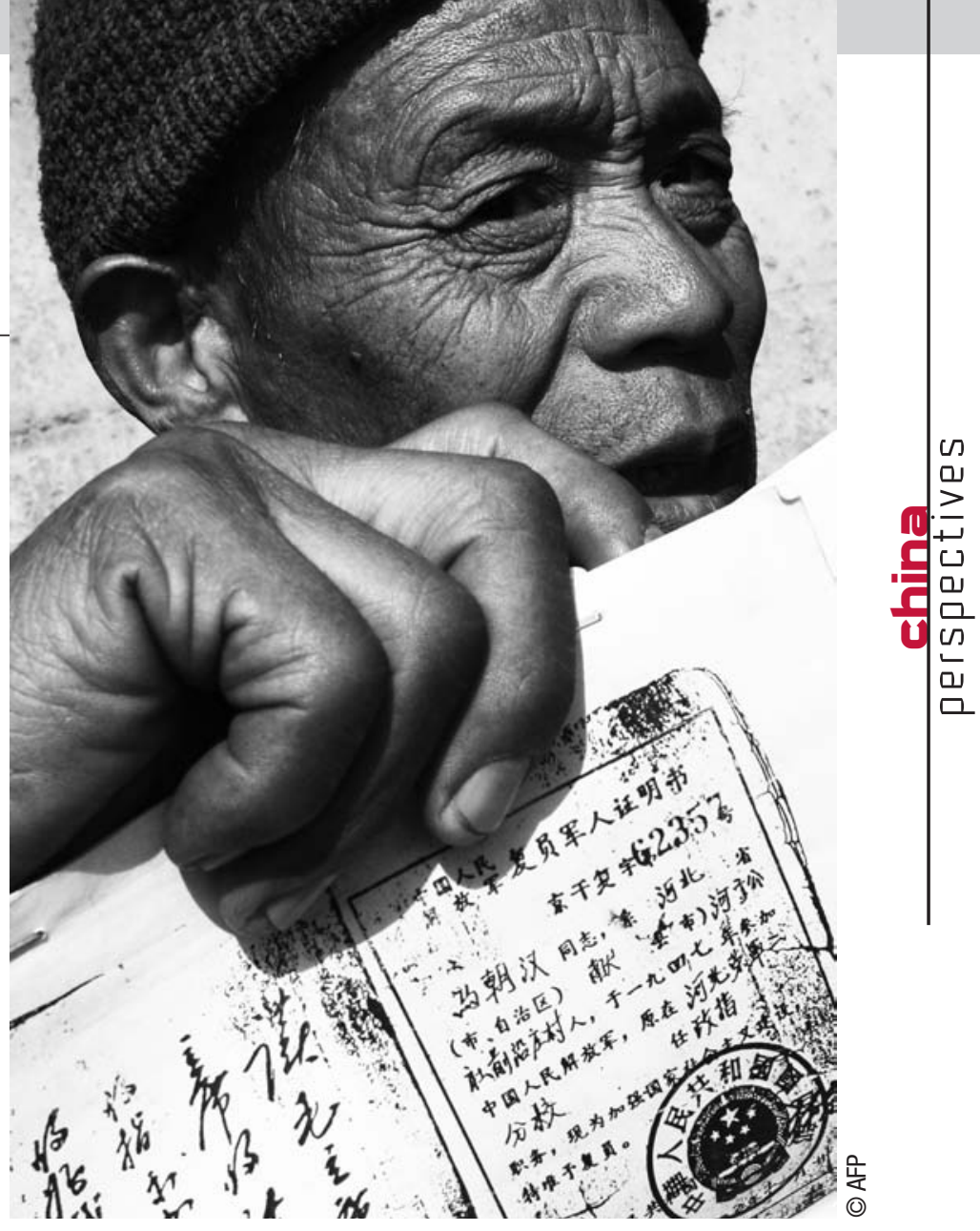

tained I was beaten so badly that blood ran down my face; I am not afraid to be detained again, I am not afraid of jail, and furthermore I want to tell you that I am not afraid to die! Implementing the central government's policies requires me to support the policies that benefit the peasants, and I will defend them to the death. I work for the Party, not for myself. Where my own business is concerned, settling accounts would require the government to pay me at least 1,000 yuan. But I never talk about my own affairs. I sat in jail for seven days and had to pay 200 yuan for my room and board. In addition, when I had to spend 45 days recovering at home, where I couldn't do anything, I said nothing to you, the government, because I am demanding that you act according to Party policy. I don't regret anything I have done. I am not doing this for myself, I am only thinking about the masses. ${ }^{(7)}$

We can see that Liu Defa's use of the phrases, "to do things according to Party policy", "not doing this for myself", and "thinking about the masses", are the most fundamental expression of the "interest" of the leaders of the peasant rights defence movement. Of course, this does not mean the movement's leaders have no personal interests at stake. Hong Jifa,

5. Ling Chunwei's interview, 9 April 2004.

6. Ling Xuewen, interview, 20 January 2003.

7. Liu Defa's interview, 12 April 2004. 
who once led the peasant rights defence movement and was imprisoned for two years, clearly expressed his personal goals:

I act for the masses, and my demand is for the Party and the leaders at all levels to reduce the burdens of the peasants; only then will I relax. My own personal demand is that my position be made clear to the masses. I don't intend this for my own reputation or profit. I, Hong Jifa, uphold justice, and I was unfairly sentenced to two years. I ask that the people's government of Hengyang County present me with a red flower to wear [a symbol of heroism given by the government], and that the administrators of the four townships attend the ceremony; I am not interested in financial restitution. ${ }^{(8)}$

Hong Jifa's "personal demands" have to do with political "rehabilitation". In fact, under the negotiation process subsequently held with the local government, county and township officials repeatedly offered to give Hong Jifa a subsidy so he would stop petitioning the authorities, organising the peasants, and making propaganda. But every time they did so, Hong Jifa refused, saying it was not "a question of money but a question of integrity." (9)

\section{Action Regulations and Legal Order}

Theoretically speaking, "the notion of legal order involves the fact that the actors believe there are concepts of action orientation, and ideas about the order of action norms." ${ }^{(10)}$ "For action, especially social action and in particular certain kinds of social relations, it is possible to take participants' existing notions of legal regulations as their orientation. The opportunity for such things to really happen must be called the 'applicability of related systems.'" (II) The question is: How do peasant rights defenders understand "legal order"? From the perspective of the leaders of the rights defence movement in Hengyang County, the scope of their actions is restricted to "what is permitted by law", and whether they do propaganda work, petition or report to the police, or create informal organised networks, they consider their action within the bounds of "legality". However, deeper examination reveals considerable complexity in the way leaders of the Hengyang County rights defence movement define legality. Although many scholars have found that the concept of "law" has specific meanings in the minds of the peasants, few scholars have critically analysed exactly what these spe- cific meanings are. Ling Chunwei, who has been referred to as a peasant legal scholar, says:

The constitutional laws are documents arrived at through mutual exchange, mutual co-ordination, and mutual compromise between the highest ruling group of a nation, under their own historical conditions, and those who are ruled within the nation; its demands are mutually adhered to and mutually binding. In other words, these are the rules of the games that allow more than 1.3 billion Chinese people covering an area of 9.6 million square kilometres to act freely. Once law loses its binding force, when nobody respects it, then these rules of the game are shattered; the public order of the whole country will be impossible to maintain, the state will lose its ability to control the people, and a state that has lost control is doomed. If the present government does not seriously implement the rules of the game it has established, then lawbreakers will run amuck, and legal rights and interests will be repeatedly infringed, causing people who defend their rights and interests in accordance with law to struggle against those who illegally encroach upon the rights and interests of others. The actions adopted by this government are an indication of its sincerity; sincerity towards the law and towards the people can convince the people that it is a good government, and unite the people behind it. With people united behind it, the government becomes a powerful and immovable force, and any incorrigibly corrupt forces that come before it will be rolled up and thrown into the garbage can of history. Failing this, the people will spit on the government and cast it aside, and history will pass it by. ${ }^{(12)}$

We might say that Ling Chunwei's understanding of the definition of law surpasses that of many legal specialists. His understanding of the relation between law and government is precisely the basis of this action to protect rights according to the law. What is especially important to point out is that, as I have discovered, the "law" used by the leaders of Hengyang County's rights defence movement is pieced to-

8. Hong Jifa's interview, 9 April 2004.

9. Hong Jifa's interview, 28 January 2003b.

10. Parsons, T, op. cit..

11. Weber, Max. Jingji Yu Shehui (Economy and Society). Shangwu Yinshu Guan, 1998, p 62.

12. Ling Chunwei's interview, 9 April 2004. 
gether from the formal law of the different organs of the national legislative structure, along with documents from the Party Central Committee, the State Council, the various ministries and State Commissions, and even leaders' speeches; this is what they take as law. Even more important to understand is that their recognition and acknowledgement of law is based on their own methods and standards, and the most important of these standards is the principle of interest; in other words, the laws that they accept and acknowledge are unquestionably those that are in their interest, or at least that they believe to be in their interest. When they undertake unlawful resistance against the local government, they do so in the name of the policies and laws of the central government. Hong Jifa's explanation of law is very interesting:

From the township downward, provisions are arbitrarily received and arbitrarily enacted, and the masses are unwilling to abide by them. I say that we will abide by those parts that are in accordance with the original regulations issued from the central and provincial governments. It is the Central Committee that has given us land to till, so we must act according to the centre's policies, and it is acceptable to pay taxes. But the other parts, we won't pay; they have to be prohibited because they betray the policies of the centre, the province, and the municipality, and are illegal. ${ }^{(13)}$

Clearly, the law as understood by Hong Jifa consists of the documents and policies that alleviate the burden of the peasants, whether they are issued by the centre, the province, or the municipality. On this point, Ling Chunwei is even more unequivocal. He says, "Law definitely stands on the side of the common people. I work according to the policies of the Party, and every step I take relies on law, so it is almost impossible for you to cause me trouble; these are your laws and policies, so you can't say that I am wrong." (14)

Here, we see that the "fairness" and "justice" of the law is measured by whether it "stands on the side of the common people". So how do the peasants regard regulations that are injurious to their interests? After Hong Jifa was sentenced to three years in prison over this issue of alleviating the burdens of the peasants, his understanding of law underwent a transformation that might help clarify the issue. Hong has repeatedly indicated an intention to use his own methods to deal with the injustices he suffered, because the law was unable to give him justice. Peng Rongjun had this to say about the legality of these activities:
When Hong Jifa was released from jail, he was so angry that he said he wanted to kill so and so. I told him not to be like that: you were imprisoned for the sake of the peasants and you shouldn't resort to illegal activities. I straightened him out on this and told him my position: "Old Hong, you can do what you like, but don't break the law; if you break the law then don't drag me into it. If you listen to me and do as I tell you, I will support you when you do what is right, and I will prevent you from making mistakes and breaking the law. Now I must control your actions. If your motives are not correct, I will denounce you to the public security bureau." As a result, he watched his step. He can work for the masses, but not illegally. All I can do is give him some good advice. ${ }^{(15)}$

Can we say that Peng Rongjun completely understands "law"? Do his actions go "beyond the bounds"? In one of his studies, Li Lianjiang once noted, "Organisers of lawful resistance have not, as they had proclaimed at the very beginning, guaranteed that every one of their actions must obey the state's policies and laws." (16) In fact, under certain conditions, the leaders of the rights defence movement still sometimes adopt illegal methods to deal with illegal practices. At the beginning of 2003, Peng Rongjun used "illegal" methods to deal with a school's arbitrary collection of tuition fees. He said:

This year the voluntary contribution to tuition fees was unexpectedly high. If it was excluded from the fees, they were not very high; in Hengyang County, the standard fees of Zhajiang are relatively stable. According to the documents issued by the municipality and the documents put out by the finance department, the commodities pricing department, and the department of education, it is forbidden for anyone to increase the voluntary contribution. Last year they combined two books into one, and under all sorts of pretexts they did not distribute the schoolbooks they were supposed to hand out to the stu-

13. Hong Jifa's interview, 22 Jan 2003a.

14. Ling Chunwei's interview, 9 April 2004.

15. Peng Rongjun. Interview, 29 December 2002.

16. Li Lianjiang and Kevin O'Brien. "Dangdai Zhongguo Nongmin de Yifa Kangzheng" (The Lawful Resistance of Contemporary Chinese Peasants), Wuguo Guang Zhulian, Jiuqi Xiaoying, Taipingyang Shiji Yanjiusuo, 1997. 
$\pi$

dents. During winter break, they collected another 15 yuan from each student for the winter break homework texts, taking in a total of tens of thousands of yuan. I told them they had to give back the excess money they had collected from Yantian to the family heads, but they did not, and a verbal dispute ensued. After trying unsuccessfully to talk to them about this, I held the schoolteacher's motorcycle at my place, and what I did was illegal. In a word, at that time I said: If you give back to the peasants what you took from them, fair and square, I will give the motorcycle back to him without the slightest damage. Now it has been almost 10 days, and I still haven't given it back to him. Yesterday the policemen said: This is not good; the school broke the law, but you also broke the law, so how can they deal with this? I have to act rightly toward the school, and also to you. He said the best thing I could do would be to give the motorcycle back, but I said, That is impossible. Let's leave aside the issue of the tuition. What has been taken in excess, let's forget about it, but you must intervene and require that they don't impose unreasonable taxes this year, and then I will give back the motorcycle. The government issued a report on this, and the school district did not come after me. If you want to arrest me, at most you can detain me for 15 days, but if you detain me for 15 days, when I am released I will sue you. ${ }^{(17)}$

From this we can gather that the peasants use the law as a kind of weapon in their rights defence movement, and that when determining the bounds of their actions, they sometimes adopt marginal tactics, like hitting an edge ball in Ping Pong. Xiao Tangbiao's research has discovered that

...the peasants' choice of methods to express their opinions to the government depends on their confidence in the authority of the government and current regulations. This reflects their faith in the Party and the government and their value orientations. In other words, in dealing with the government they have certain beliefs and perspectives that allow them to adopt relevant action methods. When they have complete faith in the upper levels of the Party and government organisations, then they always opt for "discussion". When their faith in the upper levels of the Party and government is not completely lost, they may adopt "compelled" action. If they have completely lost faith in all levels of Party and government organisations, then they may adopt "antagonistic" action. ${ }^{(18)}$

This analysis is very meaningful, and can provide us with a clear picture of peasant action. But no matter how we define the actions of Peng Rongjun and others, we can still say that the peasant rights defence movement acknowledges a certain type of "legal order" as a premise and foundation. This "legal order" consists of all regulations involving "the regulations of the Party centre" that "stand on the side of the common people" and are "in the peasants' interest". In the words of Lu Xuewen: "Wherever there is oppression, there is resistance; the more you suppress me the more I will resist. Because these policies are given to me by the Party centre and are not of my own invention, I will use the constitution and the policies to protect myself. I will recover my political rights and will not allow other people to strip me of them." (19)

\section{Methods of Action and Social Conventions}

Taylor has pointed out that the action relationships among the peasants during uprisings and rebellions are not isolated and one-off relationships, but rather have been established within rural communities over generations, and for that reason, the choices they confront must be analysed in terms of "iterated games". At the same time, the "iterated games" advanced by the peasants are undeniably influenced by the characteristics of the rural communities of which they are part. In Taylor's view:

In the relative confinement of the generational associations among people in their interdependence in rural communities where everybody knows everybody, there is formed a kind of "give and take" action norm among the people. The various social action norms are beneficial elements that help the peasants extricate themselves from various predicaments, and they invisibly mediate action among the peasants. Since everybody, after an insurrection or

17. Peng Rongjun's interview, 27 February 2003.

18. Xiao Tangbiao, "Ershinian Lai Dalu Nongcun de Zhengzhi Wending Zhuangkuang" (20 Years of Stability Among the Peasants on the Mainland), Ershiyi Shiji, 4, 2003.

19. Lu Wenxue's interview, 22 January, 2003. 
an uprising, still needs to live together and deal with each other, it is best that everyone actively participates whenever something needs to be done. Any form of action that pursues personal gain through questionable transactions, like taking small benefits without paying for them, will cause a person, when the action is over, to be isolated from the community, and he will never again be able to lift his head to face others. ${ }^{(20)}$

The peasants of Hengyang County provide absolute verification of these summations and explanations by social theorists. The simple words of Hong Jifa express the same idea:

After I told my wife about my work to organise everybody to alleviate the burdens of the peasants, she advised me not to do it: "Alleviating their burdens is not something for you to take on alone; your money will be reduced, divided up so that you won't have even a cent and you won't be treated well by anybody." At that time I had not yet been imprisoned, and I said it didn't matter whether I was treated well or not: "The people don't know, but Heaven knows"; this is all superstition. I said that the people have sharp eyes; if I help the people to have their burdens reduced, this will have an impact on them, and from generation to generation, their sons and grandsons will remember it. To die in the interest of the people is more significant than Mount Tai. When I said that, my wife told me to do what I want: whatever you want, just do it. After I finished speaking, my wife came to agree with me, and I joined Peng Rongjun's representative movement to alleviate the burdens. ${ }^{(21)}$

I am sacrificing all of my interests, including the financial damages I suffered, so why do I still want to appeal to the authorities? Because I have been influenced by Mao Zedong Thought. I was born into the new society and I grew up under the red flag; the Party Central Committee and all levels of the provincial government all share this spirit. Therefore I will uphold justice for everybody; this is the great tradition of the people of Hengyang County. ${ }^{(22)}$

What is "the great tradition of the people of Hengyang County"? It is something not casually spoken about by the leaders of the Hengyang County rights defence movement, but it has a clear and definite subject, namely Xia Minghan, a native of Hengyang County who is recognised as a hero in local hearts. Many times I heard leaders of the rights defence movement recite the soul-stirring poem about the uprising led by the martyr Xia Minghan: "If your head is cut off it's of no importance; as long as your ideas are correct, even if Xia Minghan is killed, many others will follow." The times I heard the poem, the names Peng Rongjun, Hong Jifa, Ling Xuewen, and others replaced that of Xia Minghan. But what really moved me was the peasant propagandist Liao Zhehui. He recounted the time when he was arrested for propagating the Party's policy to alleviate the peasant's burden.

The policeman said, "Liao Zhehui, you are suing the township government in the name of alleviating the burden of the people, and you are a reactionary and an enemy of the Party. If the township government can't do anything to you, I, as a policeman, can do whatever I want. You are a troublemaker and I will put you down. You talk about alleviating the burden of the peasants, but your alleviation is no alleviation; all of the peasants have given you two yuan each, so you have added to their burden. The township government takes money and gives it to the state financial administration, but this money given to you is unjust wealth. However much was given by each household, however much was given by different organisations, however much was given in total, you must give it to me, down to the last cent." He kept talking to me like this all the time we were on the road. When we drove out of the area where I live, a steel plate over the wheel of the policeman's truck broke, and as we kept going there was a terrible noise. He asked how it could be fixed. I said it's your black heart; you don't enforce the policies of the Party, and heaven and earth will not allow you to go on in this way. He said, "Ah! You still keep on about this!" In the back of the truck there was a steel shaft, and he pushed me back there... The steel plate underneath was broken, so we walked to Taiyuan, but there wasn't a steel shaft that would fit, so we had to go back to

20. He Gaochao. Dizhu Nongmin Gongchandang (Landlords, Peasants, and the Communist Party), Oxford University Press, New York, 1997, p. 56.

21. Hong Jifa's interview, 28 January $2003 \mathrm{~b}$.

22. Hong Jifa's interview. Jan. 22, 2003a 
Hengyang City to get one that did, and they held me there for half a day. Evening came and it was getting dark, and the policeman gave me two apples to eat. Then he came over to me and said, "Your organisation still has backers, it has members; whoever they are, tell me. I will act according to policy; I will get these people and kill them, and if they continue I won't stop; it will be just like a certain township in Henan." I said, if your ideas are correct, if you kill me, Liao Zhehui, then many others will follow. If you put me down, there will be more to follow. He said, "You are just like Xia Minghan! How can the people follow you!" (23)

When Liao Zhehui was telling this story, his tone was calm, and it made me feel a little confused and sad; the martyr Xia Minghan had been up against "reactionary members of the Kuomintang", but when the leaders of Hengyang County's rights defence movement loudly proclaim this poem today, they are facing the government for which Xia Minghan sacrificed his life. Yet, the meaning with which they invested this poem is exactly the same: "To die for the interest of the people is more significant than Mount Tai." In their view, the political value of this "revolutionary tradition" bestows their action with a fundamental justice and an ultimate, unsurpassable moral power.

What we particularly need to make clear is that "good traditions" such as those in Hengyang County are common throughout the countryside of central China, particularly in the old revolutionary regions. We may consider these traditions a cultural phenomenon, and most of these cultural expressions have become an inherited standard of action. In fact, these inherited standards have become an important mechanism in prohibiting the taking of small benefits without paying for them. Transforming a tradition into a method of action, and transforming it into a duty for the actor, undoubtedly requires many internal links and mechanisms.

\section{A simple Summary: Legal Government}

Chinese academics have used the concept of "lawful resistance" to explain the current peasant rights defence movement. Within the framework of this explanation, the movement has already developed from a natural right defence movement to a clearly political rights defence movement. ${ }^{(24)}$ Our research strongly supports this conclusion. But we need to go further and note that the "lawful resistance" of Chi- nese peasants today, regardless of the involvement of "interest", "order", or "convention", has one common characteristic, which is its legal nature. Precisely because of this, the politics demonstrated through the contemporary Chinese peasant rights defence movement should be considered "legal politics". •

This article is a modified version of a paper originally published in Social Research: An International Quarterly of Social Sciences, vol. 73, n 1, Spring 2006.
23. Liao Zhehui's interview. June 14, 2003.

24. Yu Jianrong, "Dangdai Zhongguo Nongmin de Weiquan Kangzheng" (The Resistance of the Peasants in Contemporary China). Paper, Zhongguo Shehui Kexueyuan Nongcun Fazhan Yanjiusuo, 2004a, and "Dangqian Nongmin Weiquan Huodong de Yige Jiesh Kuangjia” (An Explanatory Framework of the Peasants' Rights Defense Movement). Shehui Xue Yanjiu, 2, (2004b). 